\title{
An integrated wildlife/forest management model: Accommodating traditional Innu activities and forest management practices ${ }^{1}$
}

\author{
by Steve Morel$^{2}$ and Louis Bélanger ${ }^{3}$
}

\section{Introduction}

For many First Nations, economic development based on the natural resources of their ancestral lands is the best approach to take (Kitchen 1994, CAM 1979). When such opportunities arise, however, the challenge consists of merging cultural and development practices. The challenge is all the greater when resource development is planned in areas where traditional activities are also practised (NAFA 1993). Many communities are prepared to open dialogue and to establish a basis for cooperation that will ensure the harmonious cohabitation of First Nations peoples and Quebeckers within given areas. According to Matchewan (1992), for example, the Barrière Lake Algonquins wanted the governments to work with them for the sustainable development of their ancestral lands. In similar cases, according to Kitchen (1994), timber companies must consider First Nations peoples as partners having a stake in allowing sustainable resource development. The need for taking First Nations peoples' concerns into account in forest management planning is acknoweledged in the National Forest Strategy (Canadian Council of Forest Ministers 1992).

The Innu Nation, with nearly 12,000 members, is one of the largest in Quebec in terms of population (Government of Quebec, 1992). There are eight Innu communities on the north shore of the St. Lawrence and one in the Lac-Saint-Jean area. Once a nation of hunters and gatherers, the Innu have gradually become a sedentary people, although they continue to practice traditional activities in forested areas.

Economic development based on their natural resources is an important element of the societal project espoused by Innu communities (CAM 1979). Their goal is to maintain their relationship with Mother Earth and preserve their culture in a modern-day context (Cleary 1993). But the Innu are faced with a dilemma with respect to the development of their forest resources. Some community members want to proceed with economic development within their territories, whereas others want to ensure the continued capacity of these territories to sustain the practice of traditional activities.

From the Innu's perspective, there is a need to find solutions to ensure the harmonious implementation of forest management practices and their traditional activities in a given area. Past forest practices disrupted the Innu's use of their lands, whereas those resulting from the 1986 Forestry Act only partially meet the needs or address the concerns of many communities. A management model + called the integrated wildlife/forest management model + is offered as a solution. The model is the result of research undertaken as part of a Master's degree

\footnotetext{
${ }^{1}$ This article was previously published, in French, in the December 1997/January 1998 issue of the journal l'Aubelle, and is based on research leading to Mr. Morel's Master's degree.

${ }^{2}$ Member, Innu Nation, Mushteniatsh

${ }^{3}$ Professor, Université Laval, Quebec.
}

in Forestry (Morel 1996). Discussions were held with Innu trappers in order to analyze their perceptions of forest management and to see how their needs and concerns with respect to the territory could be taken into account in forest management planning.

The proposed model could be implemented in territories where hunting and trapping activities are carried out, such as a controlled harvesting zone (ZEC), outfitter territories and wildlife reserves. The model was developed from the perspective of land use by the Innu for traditional activities. The model therefore focuses on maintaining a territory capable of supporting trapping, hunting, fishing or gathering by the Innu consistent with their relationship with the land.

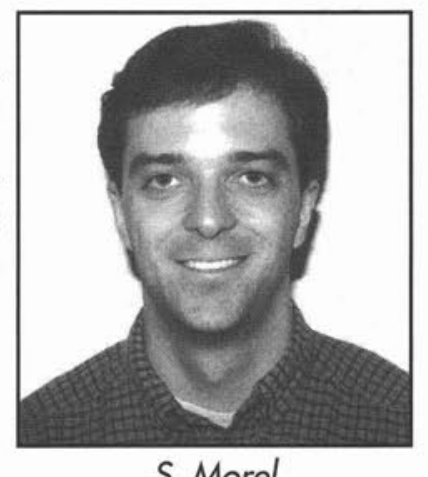

S. Morel

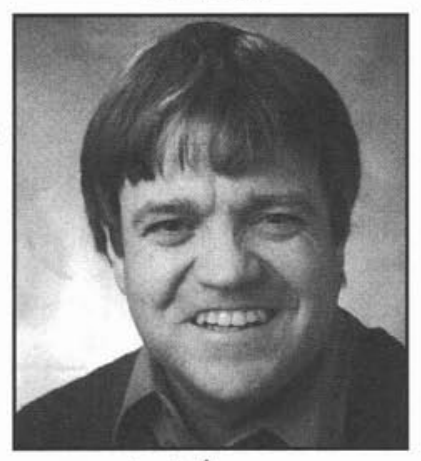

L. Belanger

\section{The Integrated Wildlife/Forest Management Model}

The integrated wildlife/forest management model is based on four guiding principles. These are consistent with the principles of sustainable development and the harmonious cohabitation of non-natives and the Innu in forested areas. These principles can be stated as follows:

- Forest management practices must preserve or improve the quality of wildlife habitat over the entire trapping territory;

- Forest management practices must preserve the integrity of the areas used by the Innu;

- Decision-making during the forest management planning phase must be achieved on a consensual basis;

- Integrated forest management practices should be encouraged.

\section{Preservation or Improvement of the Harvested Wildlife Habitat}

Past forest practices disrupted the land-use traditions of the Innu (Brassard 1987, Morel 1996). By modifying the forest structure within a given territory, forest management activities have an impact on wildlife habitat. Its capacity for supporting traditional Innu activities may also be affected. Accordingly, the habitat needs of harvested wildlife species must be taken into account in the development of forest man- 


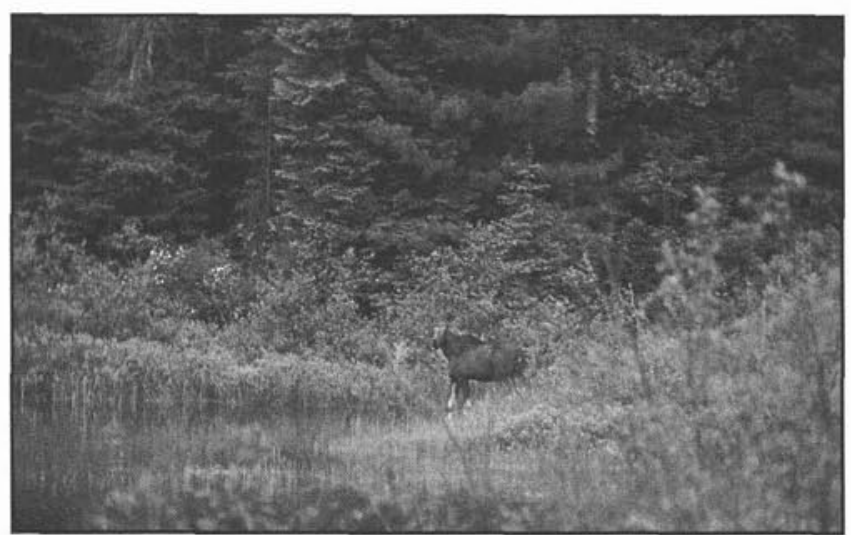

Fig. 1. Harvesting operations and habitat management for a wildlife species such as moose can be complementary.

agement plans in order to meet the needs of Innu trappers and hunters.

We are convinced that forest management and wildlife habitat management can be complementary activities (Figure 1). It is, in fact, possible to preserve, even to improve, a given area's capacity for suporting the species harvested by the Innu. Sound forest management planning can contribute to improving the habitat of several species. It can also alleviate the negative impacts on the habitat of species which depend chiefly on mature and overmature stands (Figure 2). It is imperative, however, that preservation of harvested species habitat be achieved over all the trapping territory.

\section{A landscape management mosaic}

The scheduling of harvesting operations must be such as to result in a landscape mosaic favourable to the harvested wildlife species. In the medium term (e.g., 15 to 25 years), forest harvesting can be beneficial to species associated with young forests. In the short term, however, studies in the Quebec boreal forest indicate that recent cutovers, even those which include regeneration cuts, are hostile ecosystems for wildlife, akin to wildlife deserts (Courtois et al. 1996a, Ferron et al. 1994, Alvarez 1996, Turcotte et al. 1994, De Bellefeuille 1997, Potvin 1997). This state of biological aridity usually lasts up to the sapling stage (height $>4+7 \mathrm{~m}$ ). That is when vegetation is sufficient to provide the requisite browse and cover for several game and fur-bearing species to survive.

- The capacity of wildlife communities to survive in harvested areas $\left(<50 \mathrm{~km}^{2}\right)$ during the cutover stage depends on the nature of the remaining forest. This is particularly true for:

- the main herbivores of the boreal forest, including the snowshoe hare (Ferron et al. 1994, De Bellefeuille 1997); moose (Courtois et al. 1996a), the ruffed grouse (Dussault et al. 1995) and the spruce grouse (Turcotte et al, 1994);

- several forest predators, including the American marten (Thompson 1988, Alvarez 1996, Potvin 1997); and

- songbirds (Darveau et al. 1995).

From an integrated wildlife/forest management perspective, managers must pay as much attention to the residual forest (stand area, vegetation strips between stands) as they do to cut block characteristics (size and shape). In this connection, the landscape management approach is in order.

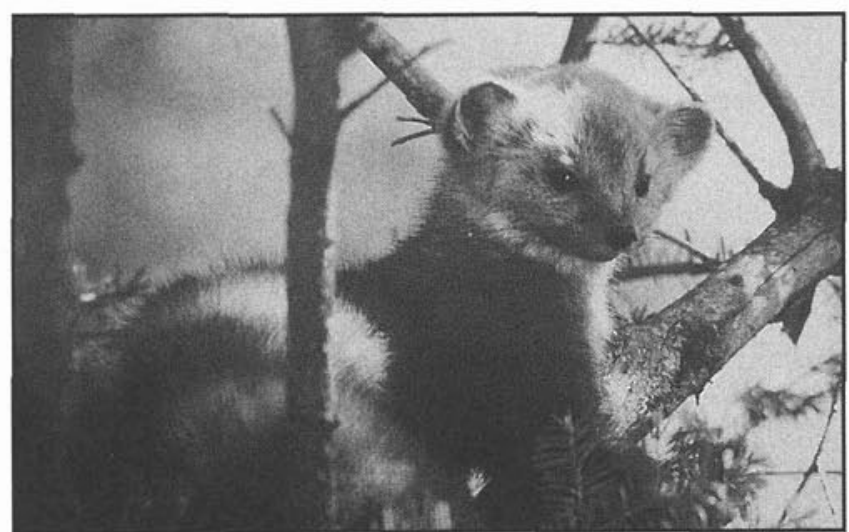

Fig. 2. The negative impacts of harvesting operations on the habitat of species which depend primarily on mature and overmature stands can be alleviated.

\section{Landscape management over the entire trapping territory}

In order to preserve or to improve the habitat of harvested wildlife species, the objectives of landscape management must take into account the use of a given territory by Innu hunters and trappers. Landscape management must be implemented throughout the trapping territory (Figure 3 ). The trapping and hunting territory represents the actual territorial occupation unit of many Innu. This occupation, along with wildlife resource needs, must be reflected in forest management plans (Mongeon 1993a). In this connection, in the context of preserving biodiversity, Potvin and Bélanger (1995) introduced the wildlife production unit (WPU) concept as a tool for managing the habitat of harvested species. In their opinion, the WPU area should be equivalent to the area of the trapping or outfitter's territory. It should cover anywhere from 100 to 500 $\mathrm{km}^{2}$ and serve as the basis for setting the requisite habitat objectives for achieving wildlife production targets. Accordingly, the limits of trapping territories must be taken into account when setting the limits of wildlife management units for harvested species. Accommodating the territorial reference unit (TRU) concept introduced by the Ministère des Ressources naturelles (Government of Quebec 1995) with this Innu reality is a promising approach.

Within a WPU, certain sectors could be subjected to forestry practices aimed at developing a given species' habitat. The shoreline environment is a rich widlife environment (La Rue et al. 1995), that is of particular importance for many Innu, as trap lines and migration paths frequently follow streams. Thus, forestry practices close to bodies of water should be designed to maintain their capacity to support wildlife. Certain other habitats, such as moose wintering yards, should also be protected by specific measures. In black spruce forests, for example, measures must be taken to preserve mixed stands, given their importance to moose in these areas (Groupe Dryade 1987, Germain et al. 1991).

The Innu should be involved in setting the limits of WPUs and the wildlife objectives of the species they harvest. This is a key element in reconciling forest management objectives and their occupation of the land.

\section{Preservation of the Integrity of Territorial Occupation Areas}

In their traditional activities, the Innu use a set of sites, infrastructures and migration paths. Many of these elements may 


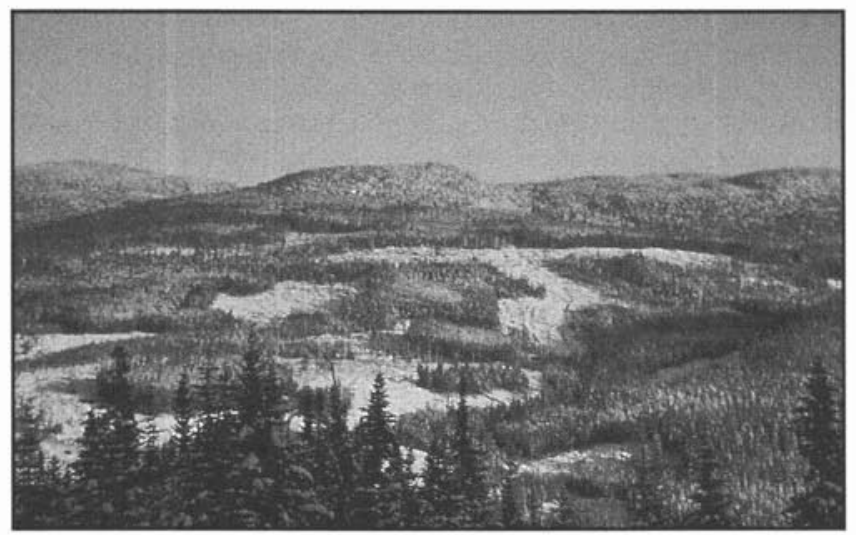

Fig. 3. The scheduling of cut blocks within trapping territories must result in a habitat mosaic which is favourable to the wildlife species harvested by the Innu.

have considerable cultural value and contribute to the strength of the Innu's relationship with Mother Earth, since they bear witness to current or past occupation of the land. These elements, and their surrounding area, must be protected. They may include main campsites, secondary campsites, historical sites, archeological sites, burial grounds, traplines, canoe routes, portage trails and gathering sites. Such areas require a specific environment and any forestry practices nearby must be compatible with their traditional role when occupied by the Innu. The Innu communities should establish a data bank of such areas and elements for inclusion in the land-use plan for any given territory. This would greatly facilitate the integration of all activities within that territory.

\section{Consensual Decision-making}

The integrated wildlife/forest management model was developed in order to foster the harmonious cohabitation of those who use the land. The effective integration of their respective needs calls for the implementation of a consensual decision-making process. This requires a commitment by the parties to arrive at the most widely acceptable solution possible (Bertand and Beaulieu 1995). This approach also fosters the establishment of effective communication among the participants (Bertrand and Beaulieu 1995). Stakeholders must be able to bring their influence to bear during the forest management planning phase and the selection of those measures that will ensure the harmonious practice of all forest-related activities. Stakeholders are persons, groups or organisations likely to be affected by the consequences of the decisions about a given territory, or who are in a position to influence decisionmaking (Bertrand et al.1994).

Each trapping territory is the special responsibility of one or several Innu managers. Their involvement in forest management planning, particularly in the development of management plans, is critical for the effective integration of their needs and concerns. Because of their knowledge of the territory, they are in a position to make a significant contribution to the preparation of integrated forest resource management plans.

The consensual decision-making process should apply to activities throughout all common occupation areas in order to meet industrial wood fibre production objectives and those of the Innu users of the land in terms of wildlife resources. Common occupation areas are those which are included in
Ministère des Ressources naturelles' Timber Supply and Forest Management Agreements with one or several forestry companies. At present, calculation of the annual allowable cut under sustained yield management is made on the basis of these areas. Potvin and Bélanger (1995) suggested using common occupation areas as sustained yield management units (SYMU). This is where sustained yield objectives for wood fibre production and the preservation of the long term biodiversity of ecosystems can be achieved.

\section{Implementation of Integrated Forest Management Practices}

In order to respect the principles observed by the Innu who occupy a given territory, forestry practices must be consistent with the principles of ecosystem dynamics. This means that forest management planning must focus on practices which foster natural regeneration and natural stand dynamics. Hunter's coarse filter approach (Hunter 1990), which involves preserving all ecosystems in order to protect all species, is consistent with the Innu vision and provides for achieving wood fibre and wildlife production objectives as well as recreational objectives (Bélanger 1995).

This principle of the integrated wildlife/forest management model must nonetheless be balanced by the principle which calls for preserving the quality of the habitat of harvested widlife species. The Innu territory consists in part of black spruce stands. In the past, the dynamics of these stands were governed by fire. Regeneration cuts, occasionally followed by reforestation, have partially replaced fire in black spruce stand dynamics. Given the direct and indirect impacts of forest harvesting on land occupation by the Innu, it is important to distinguish forestry practices that are consistent with natural principles from those that imitate nature. Thus, a maximum cut area must not be justified by the fact that fire would have destroyed the same area of forest land in absence of forest fire control measures. The distribution and size of cut areas, while based on natural disturbance mechanisms, must nonetheless be planned in accordance with the current occupation of the land by the Innu. This approach accommodates the concerns of Innu trappers with respect to the natural environment in a context where management objectives take their current needs into account.

\section{Conclusion}

In the past, the absence of consideration of the needs and concerns of First Nations peoples in the forest management planning phase led to several conflicts in forested areas. Integrating traditional activities and forest management activities is nonetheless possible. The advent of sustainable forest management should enhance the integration of the needs and concerns of First Nations peoples who occupy the land. The establishment of mechanisms allowing them to effectively participate in the decision-making process is critical to harmonious cohabitation in forested areas. This is a major issue in First Nations communities where economic development strategies include forest management activities in areas where their members practice traditional activities.

Finding solutions to the problems posed by Aboriginal forestry as a whole may require the adoption of various forest resource management approaches tailored to address specific management issues in various areas. Moreover, 
according to Mongeon (1993b, p. 18), "The management tools to be developed must first address local and regional realities linked to the socio-cultural and economic concerns of the area's inhabitants. "Examples of approaches likely to succeed include full First Nations management, co-management and the establishment of consensual decision-making round tables. Regardless of the management approach adopted within First Nations' ancestral lands, integrated management of forest resources is essential to the reconciliation of Aboriginal occupancy of the land and the conduct of forest management activities. The implementation of integrated management processes fostering the harmonious conduct of activities in forested areas is critical for achieving sustainable development and respecting those who, in fact, were the first occupants of the land.

\section{Acknowledgements}

The integrated management model proposed in this article stems from the analysis of the perceptions of Innu trappers of forest management and their concerns about the land. Special thanks are extended to these individuals and to others who helped us to establish a positive relationship with them: Mr. Daniel Courtois, Conseil des Montagnais du Lac-Saint-Jean and Mr. Normand Bacon, Société de développement économique de Betsiamites. We also acknowledge the help of Mr. Louis Guay of the Faculty of Social Sciences at Laval University with the social aspects of our research.

\section{References}

Alvarez, E. 1996. La forêt mosaïque : une alternative d'aménagement pour le maintien de la martre dans la sapinière boréale? Mémoire de maîtrise, Faculté de foresterie et géomatique, Université Laval, Québec, 36 p.

Bélanger, L. 1995. L'aménagement à l'échelle du paysage : la clé d'une foresterie qui conserve la diversité des écosystèmes. Conférence présentée dans le cadre du $19 \mathrm{e}$ congrès de l'Association des biologistes du Québec, "Biodiversité et développement : Mariage possible ?" Collection Environnement de l'Université de Montréal 19: 203218.

Bertrand, L. and V. Beaulieu. 1995. La concertation entre tous les utilisateurs évite les conflits. Opérations forestières 30(3) : 61-65.

Bertrand, L., C. Perreault, A. Rousseau, L. Bélanger and J.M. Martel. 1994. Intégration des parties prenantes dans la planification de l'aménagement forestier : Un processus de décision participative. Essais, expérimentations et transfert de technologie en foresterie projet \#3040, phase $1,79 \mathrm{p}$.

Brassard, D. 1987. L'exploitation forestière et ses impacts en territoire Atikamekw et Montagnais. Conseil des Atikamekws et des Montagnais, Québec, $160 \mathrm{p}$.

Cleary, B. 1993. Le long et difficile portage d'une négociation territoriale. Recherches amérindiennes au Québec 13(1) : 49-60.

Conseil Attikamek-Montagnais (CAM). 1979. Nishastanan, Nitasinan (Notre terre, nous l'aimons et nous y tenons). Recherches amérindiennes au Québec 9(3) : 171-182.

Conseil canadien des ministres des forêts. 1992. Durabilité des forêts : Un engagement canadien. Hull, $51 \mathrm{p}$.

Courtois, R., J.P. Ouellet and B. Gagné. 1996a. Habitat hivernal de l'orignal (Alces alces) dans des coupes forestières d'AbitibiTémiscamingue. Ministère de l'Environnement et de la Faune, Direction de la faune et des habitats, Québec, $33 \mathrm{p}$.

Courtois, R., J.P. Ouellet, M.C. Dansereau and A.M. Fauvel. 1996b. Habitat de début d'hiver de l'orignal (Alces alces) dans quatre zones bioclimatiques du Québec. Ministère de l'Environnement et de la Faune du Québec, Direction de la faune et des habitats, $24 \mathrm{p}$.
Darveau, M., P. Beauchesne, L. Bélanger, J. Huot and P. La Rue. 1995. Riparian forest strips as habitat for breeding birds in boreal forest. Journal of Wildlife Management 59: 67-78.

De Bellefeuille, S. 1997. La sapinière boréale en voie de régénération : un écosystème difficile pour le lièvre d'Amérique. Mémoire de maîtrise, Faculté de foresterie et géomatique, Université Laval, Québec, 53 p.

Dusseault, C., J. Ferron and R. Courtois. 1995. Habitat de la gélinotte huppée (Bonasa umbellus) en Abitibi-Témiscamingue et impact à court terme d'une coupe avec protection de la régénération. Ministère de l'Environnement et de la Faune, Direction de la faune et des habitats, $67 \mathrm{p}$.

Ferron, J., F. Potvin and C. Dusseault. 1994. Impact à court terme de l'exploitation forestière sur le lièvre d'Amérique en forêt boréale. Ministère de l'Environnement et de la Faune du Québec, Service de la faune terrestre, $75 \mathrm{p}$.

Germain, G., L. Bélanger, P. La Rue and L. Briand. 1991. Guide d'aménagement de l'habitat de l'orignal. Rapport soumis au ministère du Loisir, de la Chasse et de la Pêche.

Gouvernement du Québec. 1992. Les Amérindiens et les Inuit du Québec d'aujourd'hui. Secrétariat aux affaires autochtones. Les Publications du Québec, Québec, 26 p.

Gouvernement du Québec. 1995. Règlement sur les normes d'intervention dans les forêts du domaine public. Assemblée nationale. Loi sur les forêts, L.R.Q., c. F-4.1, a. 171, Gazette officielle du Québec, pp. 1381-1405.

Groupe Dryade. 1987. Moose habitat : Literature Review and Conservation Guidelines. Grand Conseil des Cris (du Québec), $79 \mathrm{p}$.

Hunter, M.L., Jr. 1990. Wildlife, forests and forestry. Principles of managing forests for biological diversity. Prentice Hall, Englewood Cliffs, New Jersey, $370 \mathrm{p}$.

Kitchen, J. 1994. Les ressources naturelles et les communautés autochtones. Allocution présentée dans le cadre du colloque "Les autochtones et la gestion intégrée des ressources." Ordre des ingénieurs forestiers du Québec, Hull, $13 \mathrm{p}$.

La Rue, P., L. Bélanger and J. Huot. 1995. Riparian edge effects on boreal balsam fir bird communities. Canadian Journal of Forest Research, 25 : 555-566.

Matchewan, J.M. 1992. Le dur combat des Algonquins du lac Barrière pour un développement durable. In Richardson, B., "Minuit moins cinq sur les réserves." Texte de huit chefs autochtones. Libre Expression, Montréal, pp. 107-134.

Mongeon, M. 1993a. L'appel du territoire. Forêt Conservation $59(10): 20-25$.

Mongeon, M. 1993b. Autochtonisme et gestion intégrée. Forêt Conservation 60(6): 18-20.

Morel, S. 1996. L'intégration des préoccupations des trappeurs montagnais à l'aménagement des forêts du Québec. Mémoire de maîtrise, Faculté de foresterie et géomatique, Université Laval, Québec, 94 p. National Aboriginal Forestry Association (NAFA). 1993. Forest lands and resources for aboriginal people. An intervention submitted to the Royal Commission on Aboriginal Peoples, Ottawa, $39 \mathrm{p}$. Potvin, F. 1997. La martre d'Amérique (Martes americanes) et la coupe à blanc en forêt boréale : une approche télémétrique et géomatique. Thèse de doctorat, Faculté de foresterie et géomatique, Univerdité Laval.

Potvin, F. and L. Bélanger. 1995. Pour préserver la biodiversité au Québec, une approche à l'échelle du paysage forestier s'impose. Aubelle $109: 19-22$.

Thompson, I.D. 1988. Habitat needs of furbearers in relation to logging in boreal Ontario. Forestry Chronicle, 64: 151-161.

Turcotte, F., R. Couture, R. Courtois and J. Ferron. 1994. Réactions du Tétras du Canada (Dendrogapus canadensis) dans la région de l'Abitibi-Témiscamingue. Ministère de l'Environnement et de la Faune, Direction de la faune et des habitats, $57 \mathrm{p}$. 